\title{
Physical mapping and marker development for the porcine glial cells missing homolog 1 (Drosophila)(GCM1) gene
}

\author{
A. Spötter, C. Drögemüller, H. Kuiper, H. Hamann, and O. Distl \\ Institute of Animal Breeding and Genetics, School of Veterinary Medicine Hannover, Hannover (Germany)
}

\section{Rationale and significance}

The murine $G c m 1$ encodes a transcription factor that is required for placental development. It is expressed in the labyrinth beginning at the time of chorioallantoic fusion. The labyrinth fails to develop in $\mathrm{Gcm}^{-/-}$mice, resulting in death by embryonic day 10 (E10) (Anson-Cartwright et al., 2000). The essential role of GCM1 in embryonic development in mice implies that GCM1 may also serve a vital function in conceptus-uterine interactions in pigs. Most conceptus mortality in pigs occurs within the first 30 days of gestation. Therefore it is important to identify the genes that affect alterations in conceptus, uterine and placental development and to understand their modes of action and interplay in the way of reciprocal signaling between the blastocyst and the uterus (Geisert and Yelich, 1997). Here we report the chromosomal localization of the porcine GCM1 gene and the identification and characterization of a GCM1 associated microsatellite marker.

\section{Materials and methods}

$B A C$ isolation and microsatellite identification

For the isolation of BAC clones containing the porcine GCM1 gene, highdensity clone filters of the porcine genomic BAC library RPCI-44, constructed in pTARBAC2 (Fahrenkrug et al., 2001), were screened with a ${ }^{32} \mathrm{P}-$ labeled human GCM1 cDNA probe according to the RPCI protocols (http://

Database Accession Numbers AJ581159, AJ586611, AJ586808

The authors wish to express their appreciation to the H. Wilhelm Schaumann Foundation, Hamburg, Germany, for supporting this work by a grant.

Received 18 November 2003; accepted 15 January 2004.

Request reprints from: Dr. Andreas Spötter

Institute of Animal Breeding and Genetics

School of Veterinary Medicine Hannover

Bünteweg 17p, 30559 Hannover (Germany)

telephone: +49-511-9538877; fax: +49-511-9538582

e-mail: Andreas.Spoetter@tiho-hannover.de. www.chori.org/bacpac/). The cDNA clone IMAGp998J128597 required for this purpose was obtained from the Resource Center/Primary Database (http://www.rzpd.de/) and was verified by sequencing and subsequent BLASTN analysis. One GCM1 positive BAC clone designated RPCI44$514 \mathrm{~K} 23$ was isolated and then verified by ECL hybridization (AmershamPharmaciaBiotech, Freiburg, Germany) using the cDNA clone mentioned above as probe. The isolated BAC DNA was restricted with different enzymes and was separated on $0.8 \%$ agarose gels. The resulting fragments were cloned into the polylinker of pGEM-4Z (Promega, Mannheim, Germany). Recombinant plasmid DNA was sequenced with the ThermoSequenase kit (AmershamPharmaciaBiotech) and a LI-COR 4200 automated sequencer. Sequence data were analyzed using Sequencher 4.1.4 software (GeneCodes, Ann Arbor, MI, USA). In a BLAST search of these sequences, one subclone sequence (AJ586611) showed $77 \%$ homology to an intron of the human FBXO9 gene. In the human genome FBXO9 is situated next to the GCM1 gene in a distance of approximately $30 \mathrm{~kb}$. Thus it is very likely that RPCI44-514K23 contains also the porcine GCM1 gene or at least parts of it. This result is yet another verification of the isolated BAC clone. A manual search for genetic markers in the determined DNA sequences of the clone resulted in the identification of one $(\mathrm{CA})_{\mathrm{n}}$ dinucleotide repeat. The flanking PCR primers GCM1_MSc: 5'-GCA GCT GTA GTT CCA ATT TG-3' and GCM1_MSd: 5'-TAA GTG AGA AGG GCT GAC C-3' were derived from the DNA fragment containing the microsatellite (AJ581159).

PCR conditions and microsatellite analysis

The PCR amplification ( $15 \mu \mathrm{l}$ final volume) was performed using $20 \mathrm{ng}$ of genomic porcine DNA, $1 \times$ PCR buffer, $100 \mu \mathrm{M}$ each dNTP, 10 pmol each primer, and 1 U Taq DNA polymerase (Promega, Mannheim, Germany). Temperature and time profile were 34 cycles of $94^{\circ} \mathrm{C}$ for $30 \mathrm{~s}, 58^{\circ} \mathrm{C}$ for $1 \mathrm{~min}$, and $72^{\circ} \mathrm{C}$ for $30 \mathrm{~s}$. The forward primer was $5^{\prime}$ IRD700 labeled to enable fluorescent PCR fragment detection on a LI-COR 4200 automated sequencer. Raw data were genotyped using Gene Profiler 3.55 software (Scanalytics, Inc., Fairfax, VA, USA).

Marker characteristics were determined by genotyping 197 boars of four different pig breeds using the above mentioned PCR primer pair.

\section{Chromosome preparation}

Porcine metaphase spreads for FISH on GTG-banded chromosomes were prepared using phytohemagglutinin-stimulated blood lymphocytes from a normal pig. Cells were harvested and slides prepared using standard cytogenetic techniques. Prior to fluorescence in situ hybridization the chromosomes were GTG banded and well-banded spread metaphase chromosomes were photographed using a highly sensitive CCD camera and IPLab 2.2.3 (Scanalytics).

\begin{tabular}{lll}
\hline KARGER & $\begin{array}{l}\text { Fax }+41613061234 \\
\text { E-mail karger@karger.ch } \\
\text { www.karger.com }\end{array}$ & $\begin{array}{c}\text { ○ 2004 S. Karger AG, Basel } \\
0301-0171 / 04 / 1061-0142 \$ 21.00 / 0\end{array}$
\end{tabular}

Accessible online at: www.karger.com/cgr 
Table 1. Characterization of the developed GCM1-linked microsatellite marker

\begin{tabular}{|c|c|c|c|c|c|}
\hline Breed & Sample size & No. of alleles & $\begin{array}{l}\text { Allele size min- } \\
\max (b p)\end{array}$ & $\begin{array}{l}\text { Expected } \\
\text { heterozygosity }\end{array}$ & $\mathrm{PIC}^{\mathrm{a}}$ \\
\hline Duroc & 44 & 6 & $131-154$ & 0.58 & 0.52 \\
\hline German Landrace & 84 & 4 & $131-145$ & 0.50 & 0.39 \\
\hline German Large White & 20 & 4 & $131-145$ & 0.44 & 0.41 \\
\hline German synthetic line & 49 & 7 & $131-154$ & 0.59 & 0.51 \\
\hline
\end{tabular}

Polymorphism Information Content.

The tested populations were found to be in Hardy-Weinberg equilibrium for the genotyped locus.

\section{Fluorescence in situ hybridization}

The BAC clone RPCI44-514K23 containing the porcine GCM1 gene was labeled with digoxigenin by nick translation using a Nick-Translation-Mix (Boehringer Mannheim Corp., Mannheim, Germany). FISH on GTGbanded pig chromosomes was performed using $750 \mathrm{ng}$ of digoxigenin-labeled BAC DNA. $1 \mu \mathrm{g}$ sheared total porcine DNA and $10 \mu \mathrm{g}$ salmon sperm DNA were used as competitors in this experiment. After hybridization over night, signal detection was performed using a Digoxigenin-FITC Detection Kit (Quantum Appligene, Heidelberg, Germany). The chromosomes were counterstained with DAPI and slides were mounted in propidium iodide/antifade. Metaphases that were previously photographed were reexamined after hybridization with a Zeiss Axioplan 2 microscope equipped for fluorescence.

Probe name: RPCI44-514K23

Probe type: BAC clone from porcine BAC library (Fahrenkrug et al., 2001)

Vector: pTARBAC2

Proof of authenticity: DNA sequencing

Gene reference: Basyuk et al. (1999)

Radiation hybrid $(R H)$ mapping

The INRA-University of Minnesota porcine Radiation Hybrid panel (ImpRH; Yerle et al., 1998) was obtained from INRA, Laboratoire de Génétique Cellulaire, Castanet-Tolosan, France. The 118 DNAs of the RH panel were subjected to PCR amplification. A 150-bp fragment of the GCM1 gene was amplified using the primers GCM1f: 5'-GAT CAT CTC AGA GAA CAG AG-3' and GCM1r: 5'-CCT TTC TCC TCA CCT ATA CC-3' (AJ586808). Temperature and time profile were 39 cycles of $94^{\circ} \mathrm{C}$ for $30 \mathrm{~s}$, $58^{\circ} \mathrm{C}$ for $1 \mathrm{~min}$, and $72^{\circ} \mathrm{C}$ for $30 \mathrm{~s}$. The PCR products were analyzed by $1 \%$ agarose gel electrophoresis and ethidium bromide staining. Positive signals were scored and the results were statistically analyzed using the IMpRH mapping tool (http://imprh.toulouse.inra.fr/).

\section{Results and discussion}

\section{Polymorphism}

Table 1 shows the respective sample sizes, number of alleles, allele sizes, expected heterozygosity and polymorphism information content. The total number of different alleles observed over all four breeds was 7 and their sizes ranged from 131 to $154 \mathrm{bp}$.

\section{Chromosomal location}

The chromosomal location of the porcine GCM1 gene was determined by FISH of the BAC clone RPCI44-514K23 to metaphase chromosomes (Fig. 1).

\section{Mapping data}

Most precise location: $\mathrm{SSC} 7 \mathrm{q} 1.3 \rightarrow \mathrm{q} 1.5$

Number of cells examined: 30

Number of cells with specific signals: 0 (0), 1 (1), 2 (1), 3 (5), 4 (23) chromatids per cell
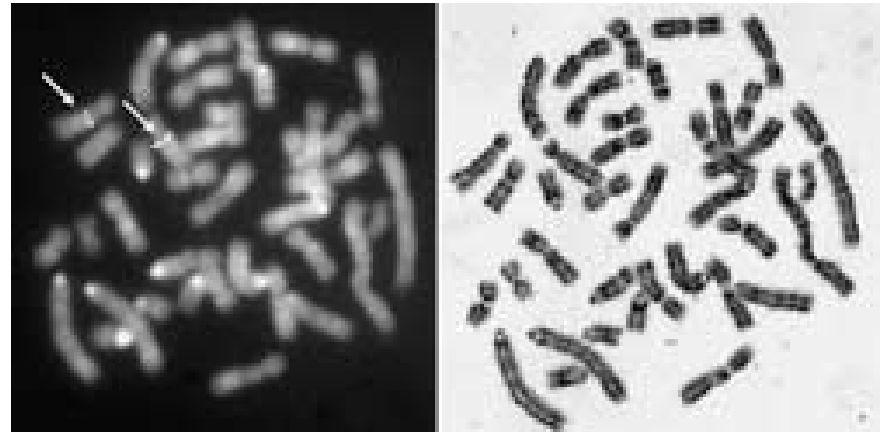

Fig. 1. In situ hybridization results on DAPI and propidium iodide/antifade stained preparations with the corresponding GTG-banded chromosomes. Double signals indicated by arrows are visible on both chromosomes SSC7q1.3 $\rightarrow$ q1.5

Location of background signals (site with $>2$ signals): none observed

In order to confirm the localization of the porcine GCM1 gene a porcine radiation hybrid panel was analyzed. The PCR primers derived from the BAC clone RPCI44-514K23 containing the gene showed a retention frequency of $27 \%$. Two-point analysis revealed close linkage of GCM1 to the microsatellite marker SWR1928 (Korwin-Kossakowska et al., 2002) at a distance of $70 \mathrm{cR}$ (LOD score 5.27). On the porcine linkage map SWR1928 is closely linked to the microsatellites S0078 and SWR1210 that have been physically assigned to SSC7q1.3 $\rightarrow$ q1.4 (Tammen et al., 1998).

In this report we mapped a porcine BAC clone containing the GCM1 gene to SSC7q1.3 $\rightarrow \mathrm{q} 1.5$. The human GCM1 gene was assigned to HSA6p12. This is consistent with the established comparative map of pig and human (Goureau et al., 1996; http://www.toulouse.inra.fr/lgc/pig/compare/compare. htm) indicating significant synteny between SSC7 and HSA6p. 


\section{References}

Anson-Cartwright L, Dawson K, Holmyard D, Fisher SJ, Lazzarini RA, Cross JC: The glial cells missing-1 protein is essential for branching morphogenesis in the chorioallantoic placenta. Nature Genet 25:311-314 (2000).

Basyuk E, Cross JC, Corbin J, Nakayama H, Hunter P, Nait-Oumesmar B, Lazzarin RA: Murine $\mathrm{Gcm} 1$ gene is expressed in a subset of placental trophoblast cells. Dev Dyn 214:303-311 (1999).

Fahrenkrug SC, Rohrer GA, Freking BA, Smith TP, Osoegawa K, Shu CL, Catanese JJ, de Jong PJ: A porcine BAC library with tenfold genome coverage: a resource for physical and genetic map integration. Mamm Genome 12:472-474 (2001)

Geisert RD, Yelich JV: Regulation of conceptus development and attachment in pigs. J Reprod Fertil 52:133-149 (1997).
Goureau A, Yerle M, Schmitz A, Riquet J, Milan D, Pinton P, Frelat G, Gellin J: Human and porcine correspondence of chromosome segments using bi-directional chromosome painting. Genomics 36:252-262 (1996).

Korwin-Kossakowska A, Reed KM, Pelak C, Krause E, Morrison L, Alexander LJ: Radiation hybrid mapping of 118 new porcine microsatellites. Anim Genet 33:224-227 (2002).

Tammen I, Hameister H, Thomsen PD, Leeb T, Brenig B: Cytogenetic localization of genetic markers on porcine chromosome 7q. Anim Genet 29:144-145 (1998).

Yerle M, Pinton P, Robic A, Alfonso A, Palvadeau Y, Delcros C, Hawken R, Alexander L, Beattie LB, Milan D, Gellin J: Construction of a whole genome radiation hybrid panel for high-resolution gene mapping in pigs. Cytogenet Cell Genet 82:182-188 (1998). 